\title{
Effect of Degradation of Municipal Solid Waste on Liquid Permeability
}

\author{
Nia Febrianti ${ }^{1}$, Benno Rahardyan ${ }^{1}$, and Febrian Hadi $^{1}$ \\ ${ }^{1}$ Faculty of Civil and Environmental Engineering, Institut Teknologi Bandung \\ J1. Ganesa Nomor 10, Bandung 40132, Indonesia
}

\begin{abstract}
The composition of food waste has a large percentage, especially in Indonesia, which gives effect to the volume of leachate that generated when the food waste is located in the landfill. Leachate is affected by the permeability of the food waste. Permeability is the ability of waste to be passed leachate or how much moisture can pass through waste as long degradation (age) of waste. Waste are degraded with the imperfect will affect the value of permeability $\left(k_{\text {liquid }}\right)$ so as to allow the water did not pass but will flow down the sides of the side of the waste. Permeability measured using ASTM method D2434-68. The results showed that age of waste has negative correlation and influential significantly to $k_{\text {liquid. }}$ Increasing the age of waste has an effect on $k_{\text {liquid, }} k_{\text {liquid }}$ tends to decrease with increasing age of waste. The range of $k_{\text {liquid }}$ is $0.10587 \mathrm{~cm} / \mathrm{s}-0.00525 \mathrm{~cm} / \mathrm{s}$.
\end{abstract}

Keywords: Municipal solid waste, age of waste, permeability, degradation

\section{Introduction}

Municipal waste (MSW) is a waste consisting of various materials with different properties. MSW is a nonhazardous waste generated from the domestic activities. Domestic waste is dominated more by organic matter, although its type and composition vary in each cities day by day (Hadiwiyoto, 1983). Characteristics of waste are includes physical (specific gravity, moisture, particle size and size distribution, field capacity and waste permeability), chemical (moisture content, volatile content, fixed carbon content, ash content, melting point of ash, waste heat value) (Damanhuri and Tripadmi, 2004), and biological properties.

One of the important parameters related to the phenomenon of MSW degradation process is permeability. Permeability is a hydraulic characteristic of MSW defined as the ability of waste to be passed by leachate, besides the mass flow studies of carbon and MSW volatile content and leachate generated will also be calculated because it has effect on the MSW volatile content based on the its age. The carbon mass balance study is used to understand how a particular element has been distributed so far in the form of major products (leachate, biogas, and solid). In this study will be observed the phenomenon of waste degradation or the occurrence of physical changes process on MSW. This research was conducted on MSW artificial waste biodegradation reactor with leachate recirculation aimed to accelerate the process of waste degradation. In addition to accelerate the stabilization process in the reactor biodegradation artificial waste also required the availability of adequate oxygen.

\section{Research Method}

\subsection{Artificial Waste of Municipal Solid Waste (MSW)}

Organic waste consists of food waste and cardboard by comparison 20 : 1 based on Bandung MSW production in 2014. The research was conducted for 60 days and total volume of sample for each reactors is 20 L.

\subsection{Reactor Design}

The reactors are made of $35 \mathrm{~L}$ HDPE drum with diameter $31.5 \mathrm{~cm}$ and its height is $50 \mathrm{~cm}$. There is a pipe and tap as gas outlet (methane and carbon dioxide) is shown in Figure 1. At the bottom of reactor there is a tap to 
remove the leachate. The reactor is placed on a wooden stand table to facilitate the leaching of the reactor. The reactor is made up of 10 drums and 10 more drums for duplo with the same garbage composition.
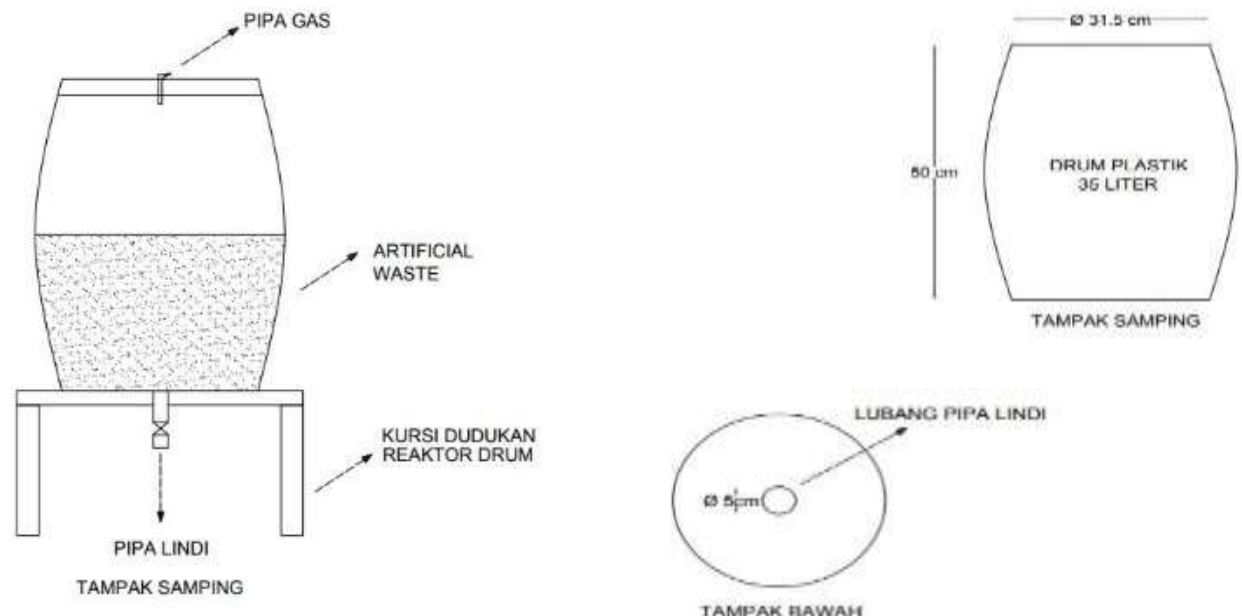

Fig. 1: Reactor Design

\subsection{Characteristic Analysis and Determination of Experimental Variation}

The waste physical charateristics analysis includes moisture content (the sample heated at $105{ }^{\circ} \mathrm{C}$ for 24 hours) and volatile (the sample heated at $600^{\circ} \mathrm{C}$ for an hours), $\mathrm{pH}$, temperature and electric conductivity (EC) as control parameters during degradation process. The parameter values are measured to determine the degradation process that occurs during the running process. $\mathrm{pH}$ of the waste sample was measured with a $\mathrm{pH}$ meter for solid, leachate $\mathrm{pH}$ measured using $\mathrm{pH}$ meter, temperature measured by thermometer.

This analysis is done before the sample was inserted into the reactor. Some parameters measured every 6 days for 60 days are density, moisture content, chemical oxygend demand (COD), VOC, and liquid permeabilities and some control paramaters measured every 2 days for 60 days are $\mathrm{pH}$ and temperature (solid and leachate). COD leachate is also measured by an open reflux method which aims to see the trend of COD values during the degradation process.

The second step of research is the variation of the reactor during the running phase, that's the variation of detention time (waste age) in the reactor, each reactor has a detention time of 6 days, until the reactor to the last 10 reactors will have the longest detention time 60 days. The $\mathrm{pH}$, temperature, and EC values are measured daily. The equation used in calculating the permeability coefficient value (k) using Equation 1.

$$
\mathrm{k}=\frac{\text { Q.L }}{\text { A.h.t }}
$$

Q is flow $\left(\mathrm{cm}^{3} / \mathrm{s}\right)$, L: sample height $(\mathrm{cm})$, A: sampel cross-sectional area $\left(\mathrm{cm}^{2}\right)$, h: total head loss $(\mathrm{cm})$, t: The time it takes to reach a certain volume.

\section{Result and Discussion}

\subsection{Physical Characteristic of Artificial Waste}

Physical characteristic parameters measured to know the effect of each parameter with others. The parameters tested to know the sample characteristic in this research are density, moisture content, and volatile content. The particle density and dry density of the waste sample are also calculated using Equation 2 and Equation 3, and then calculate the porosity using Equation 4. Test parameters were analyzed at the age 0 day sample, before the waste sample was put into the biodegradation reactor which will be seen from the degradation phenomenon based on the degradation time of the sample in the reactor. The results of parameters on the characteristics of the waste sample can be seen in Table.1. 


$$
\begin{gathered}
\rho_{p}=\frac{\text { dry weight }}{\Delta \text { water volume }} \\
\rho_{d}=\omega d \times \rho \\
\phi=1-\frac{\rho_{\mathrm{d}}}{\rho_{\mathrm{p}}}
\end{gathered}
$$

$\rho_{\mathrm{p}}$ : particle density $\left(\mathrm{g} / \mathrm{cm}^{3}\right), \rho_{\mathrm{d}}:$ dry density $\left(\mathrm{g} / \mathrm{cm}^{3}\right), \rho:$ density $\left(\right.$ bulk density) $\left(\mathrm{g} / \mathrm{cm}^{3}\right), \omega_{d}$ : dry content $(\%), \Phi$ : porosity (volume of gas and water), $\omega$ : moisture content.

TABLE I: Physical and Chemical Parameter of Artificial Waste

\begin{tabular}{cccccccccc}
\hline \hline $\mathrm{t}$ & $\omega$ & $\omega \mathrm{d}$ & $\mathrm{V}$ & $\mathrm{COD}$ & $\mathrm{k}_{\text {liquid }}$ & $\rho$ & $\rho \mathrm{p}$ & $\rho \mathrm{d}$ & $\Phi$ \\
\hline Day & $\%$ & $\%$ & $\%$ & $\mathrm{mg} / \mathrm{l}$ & $\mathrm{cm} / \mathrm{s}$ & $\mathrm{g} / \mathrm{cm}^{3}$ & $\mathrm{~g} / \mathrm{cm}^{3}$ & $\mathrm{~g} / \mathrm{cm}^{3}$ & - \\
0 & 58.59 & 41.41 & 97.74 & - & 0.21230 & 0.600 & 0.563 & 0.248 & 0.558 \\
6 & 59.51 & 40.49 & 94.00 & 4080 & 0.10587 & 0.661 & 1.495 & 0.267 & 0.817 \\
12 & 75.44 & 24.56 & 92.58 & 11000 & 0.03390 & 0.690 & 1.535 & 0.170 & 0.884 \\
18 & 28.33 & 71.67 & 82.82 & 7650 & 0.00472 & 0.710 & 1.125 & 0.509 & 0.551 \\
24 & 78.74 & 21.26 & 93.18 & 7440 & 0.08117 & 0.684 & 0.593 & 0.145 & 0.733 \\
30 & 65.62 & 34.38 & 94.07 & 7620 & 0.05441 & 0.675 & 0.890 & 0.232 & 0.748 \\
36 & 75.47 & 24.53 & 87.54 & 7140 & 0.03629 & 0.729 & 0.276 & 0.179 & 0.524 \\
42 & 68.85 & 31.15 & 97.81 & 5400 & 0.01616 & 0.712 & 0.732 & 0.222 & 0.665 \\
48 & 71.54 & 28.46 & 89.62 & 7650 & 0.01223 & 0.902 & 0.952 & 0.257 & 0.730 \\
54 & 78.55 & 21.45 & 91.70 & 7458 & 0.01687 & 0.764 & 0.862 & 0.164 & 0.807 \\
60 & 71.76 & 28.24 & 89.47 & 10080 & 0.00525 & 0.851 & 1.046 & 0.240 & 0.767 \\
\hline \hline
\end{tabular}

\subsection{Moisture Content and Volatile of Artificial Waste}

The percentage of moisture content was inscreasing during degradation process is due to the leachate recirculation to control some parameters. The effect of increasing of moisture levels affects on substrate exchange, nutrients, buffers and inhibitors dilution, and the spread of microorganisms among the microenvironment (Christensen et al., 1996. Cell plasma water is water derived from the biodegradation process which is gradually released into the pore during biodegradation process (Liu et al., 2014).

The volatile content is dried fraction lost from waste sample that heated at a temperature $600^{\circ} \mathrm{C}$ or a volatile material at $600^{\circ} \mathrm{C}$ and leaving ash. At the age of waste $\mathrm{t}=0$ days the value of percentage of volatile content of $97.735 \%$, when the waste is put into the biodegradation reactor can be seen degradation phenomenon that occurs in the waste sample to change of percentage of volatile content at $t=6$ days at $94 \%$, then the percentage of volatile at the time $\mathrm{t}=12$ days is $92.575 \%$, at the time of degradation of waste $\mathrm{t}=18$ days of volatile levels decreased to $82.824 \%$. Until at $t=60$ days the percentage of waste volatile content to be $89.470 \%$. Figure 2 shows the value of moisture content and volatile content of artificial waste.

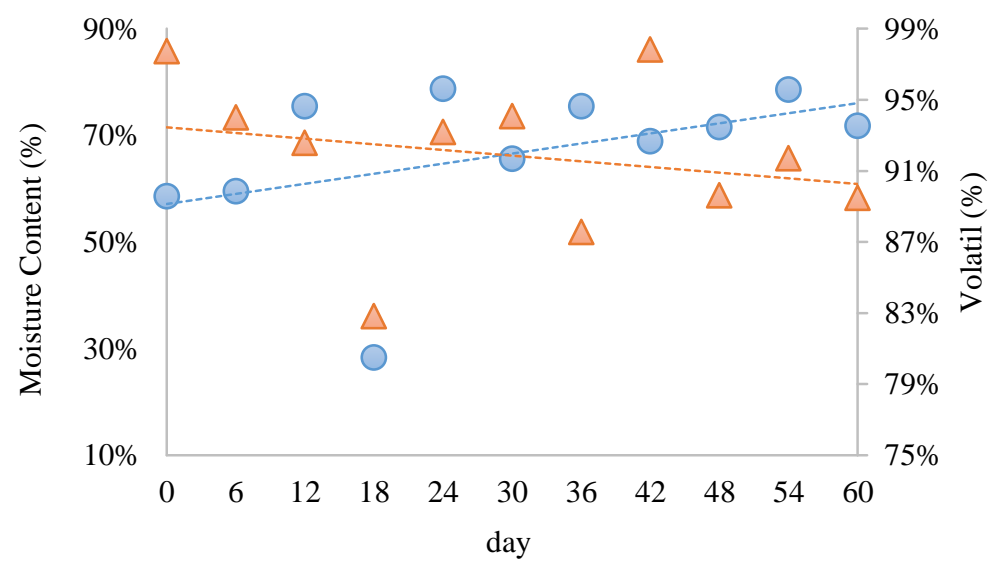

Moisture content $\triangle$ Volatile

Fig. 2: The percentage of moisture content and volatile of artificial waste for 60 days 


\subsection{Density of Artificial Waste}

The increasing of density because its height is lower and its weight is heavier, as well as changes in mass that is increasingly heavy due to the leachate generated from solid waste samples that have different specific density with solid waste samples. The phenomenon of degradation in the reactor is like a phenomenon occurring in the landfill, where in a landfill with the degradation process there is an increasing in depth the effective stress in solid waste will also increase as well as the density (Powrie and Beaven, 1999 in Hossain, et al., 2009).

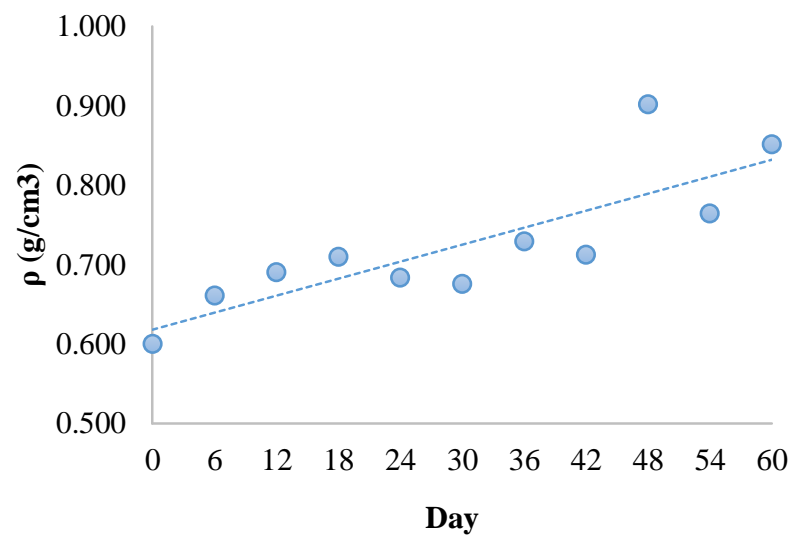

Fig. 3: Density of artificial waste in 60 days

\subsection{The Permeability liquid of Artificial Waste}

The change in the permeability coefficient value is due to the decomposition of waste particles and the increasing of the finer fraction in the waste. Increased duration of degradation will increase the subtle fraction that has significant changes in pore size, geometry of waste and continuity resulting in decreased fluid flow (Penmethsa, 2007). According to Feng, et al (2017) the flow of gas into the waste will be small if the waste sample has a low porosity and high water content.

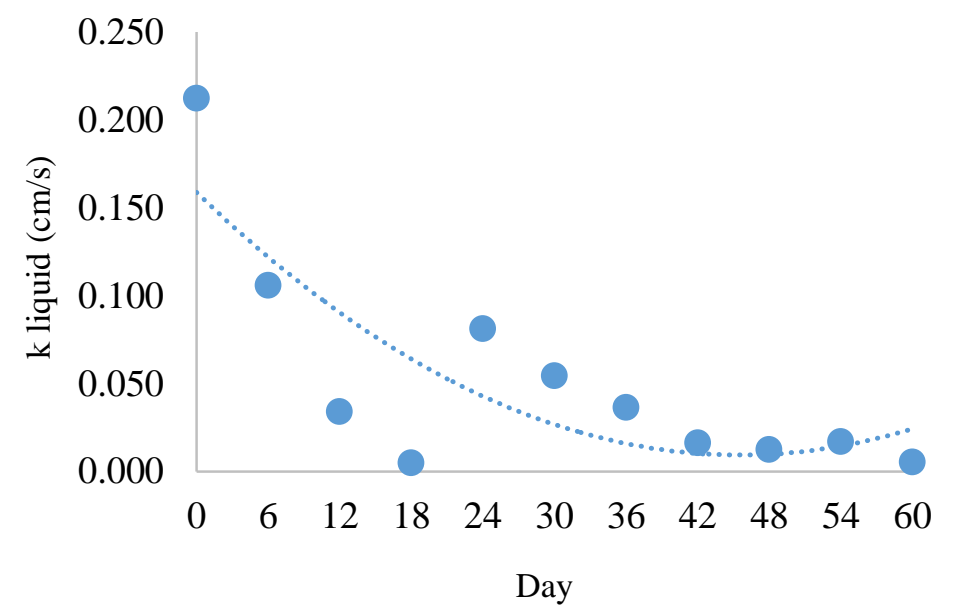

Fig. 4: Permeability liquid of artificial waste

\subsection{Correlation of Moisture Content on Permeability Liquid}

The moisture content in MSW, especially the most abundant organic waste, has moisture content of up to 74\% (Fatahi, et al., 2015). Samples that have more moisture content have a small permeability coefficient value. In this research, moisture content tends to fluctuate to the value of permeability coefficient $(\mathrm{k})$. This fluctuating nature trends can be due to the moisture content of organic samples, especially the food waste is around 60 $78 \%$. The high moisture content in the sample will occupy the pores in the garbage so that when the permeability measurement of the waste sample will pass the water less so the value of $\mathrm{k}$ becomes smaller. 


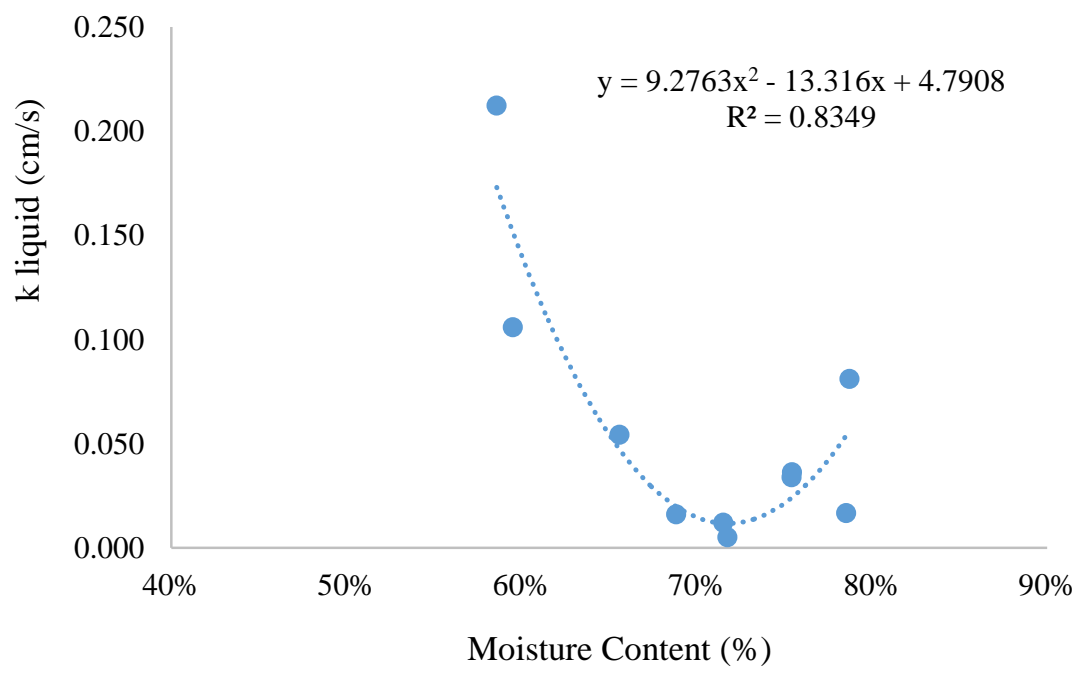

Fig. 5: Correlation of moisture content on permeability liquid

\section{Conclusion}

The value of permeability liquid $(\mathrm{k})$ on artificial waste decreased with increasing of degradation time. The most dominant water content in giving effect to the value of permeability coefficient $(\mathrm{k})$. When degradation time increases and settlement occurs very quickly so the depth of landfill will increase and life of the landfill will be longer, but if the flow of leachate in the landfill is a non-interconnected pore space then most likely leachate from waste will flow incompatible with the flow path that goes directly to the leachate collection. The permeability of liquid can be give effect for the quantity of leachate.

\section{Acknowledgment}

The research was funded by Lembaga Dana Dana Pendidikan (LPDP) of the Ministry of Finance of the Republic of Indonesia.

\section{References}

[1] Christensen, T. H., Kjeldsen, P. (1989). Basic biochemical processes in landfills, In: Sanitary Landfilling: Process, Technology, and Environmental Impact. Academic Press New, pp 29-49

[2] Damanhuri, E., Padmi, T. (2010): Pengelolaan Sampah, Departemen Teknik Lingkungan Institut Teknologi Bandung

[3] Fatahi, B., Hadi, K. (2015). Permeabilitas: Influence of Chemical Stabilisation on Permeability of Municipal Solid Wastes. Journal of Geotech Geol Eng Vol 33, 455-466. https://doi.org/10.1007/s10706-014-9831-y

[4] Feng, Shin-Jin., Zheng, Qi-Teng., and Chen, H,X. (2017). Unsaturated Flow Parameters of Municipal Solid Waste . Journal of Waste Management Vol 63 pp 107-121.

[5] Hadiwiyoto, Soewedo. (1983): Penanganan dan Pemanfaatan Sampah. Jakarta: Yayasan Idayu

[6] Hossain, M, S., K., K. Penmethsa, L., Hoyos. (2009): Permeability of Municipal Solid Waste in Bioreactor Landfill with Degradation, Geotech Geol Eng, 27:43-51 https://doi.org/10.1007/s10706-009-9265-0 https://doi.org/10.1007/s10706-008-9210-7

[7] Penmethsa, Kiran, K. (2007): Permeability of Municipal Solid Waste in Bioreactor Landfill with Degradation. Civil Engineering Research. Arlington: University of Texas.

[8] Liu, H.-L., Li, Y.-C., Chen, Y.-M. (2014). Analysis of Degradation-compression-seepage Interaction in MSW Landfills by a BCHM Coupled Model. In: International Conference on Mechanics and Civil Engineering. Atlantis Press, Wuhan, China, pp. 352-357. https://doi.org/10.2991/icmce-14.2014.60 